\title{
Racial and Gender Differences in the Returns to 2-Year and 4-Year Degrees
}

\author{
SUSAN AVERETT \& SHARON DALESSANDRO*
}

\begin{abstract}
Using data from the 1993 National Longitudinal Survey of Youth, this paper documents differences in the rate of return to 2-year and 4-year degrees across race and gender. We find for each race and gender group that a baccalaureate degree is more valuable than an associate's degree, and the return to an associate's degree is greater than attending some college, which is in turn more valuable than simply finishing high school. Our results indicate that these effects are statistically different for black and white men. Finally, according to our research, one avenue of low-cost education for women and black men is to attend a 2-year school and then finish the degree at a 4-year institution.
\end{abstract}

\section{Introduction}

Public concern about rising tuition costs, an increasingly high-tech job market, and the growing earnings differential between college graduates and those who only complete high school has led researchers and policy-makers to examine once again the issue of access to a college education and the value of that education. Recently, the Clinton Administration enacted the HOPE Scholarship that provides a tuition tax credit for $100 \%$ of the first $\$ 1000$ of tuition for 1 year and for $50 \%$ of up to $\$ 1000$ for a second year. According to a 26 September 1997 White House Press Release, this tax credit cuts tuition and fees at community colleges by $88 \%$ and in several states by up to $100 \%$. Thus, the first 2 years of an education, or a 2 -year degree, are available to virtually anyone who desires one. Several natural questions arise from this scholarship that we address in this research: What is the value of a 2-year versus a 4-year degree? Does it matter if one starts at a 2-year school and then finishes a degree at a 4 -year institution? Is obtaining an associate degree more important than simply attending some college but not graduating? Do the returns to 2-year and 4-year degrees vary by race and gender?

While a substantial literature exists on the returns to higher education in general, and a small but growing literature on the value of 2 -year versus 4 -year degrees, we 


\section{Susan Averett E Sharon Dalessandro}

still know relatively little about how the returns to 2-year and 4-year education vary by race and gender. Yet, the community college (throughout the paper, we use the terms community college and 2-year school interchangeably) remains an important source of education for many Americans, particularly those who have historically had less access to 4-year schools, typically women and minorities.

For the past 20 years, community colleges have had a significant place in society; not only by consistently enrolling approximately one-half of all first-time students, but also because their growth has been at a higher rate than for 4-year colleges over the same 20-year period (Snyder, 1997, Table 173). Many students find that the out-of-pocket costs of an education can be significantly reduced if one starts at a 2-year school and then transfers and finishes at a 4-year institution (Hoover, 1998; McCabe, 1998). In addition, community colleges are increasingly recognizing the need to have a curriculum that is readily transferable to a 4-year college (Franey, 1998; Hoover, 1998).

Two-year institutions were first created to provide increased access to higher education without creating a burden on existing 4-year institutions. Traditionally, the role of the community college has been to provide: (a) the first 2 years of a higher education, (b) vocational and career training for its community, and (c) continuing education (Morrison, 1961). Given this broad range of responsibilities, the community college as an institution must be diverse and flexible, including having open-door admissions policies. Administrators must be ready to respond to changes in market needs with curriculum enhancements, and faculty must be able to adapt teaching styles to the wide variation in student levels. It is these diverse qualities, and possibly also the decline in transfer rates to 4-year institutions (Grubb, 1991), that cause the community college, as an institution of higher education, to be looked on in a different light to traditional 4-year institutions. Many have questioned whether a 2-year education is a good investment from an economic point of view and whether it impedes a student's progress toward a 4-year degree (Dougherty, 1992). Rouse (1995) examines the probability that an individual who attends a 2 -year school will graduate with a baccalaureate degree, and finds that community colleges do not appear to change the likelihood of eventually earning a baccalaureate degree.

Through its provision for diversity in education, the community college is in a position to provide higher education to those groups, such as minorities or women, who may traditionally face more financial or competitive barriers to obtaining a college education. Recent literature (McCartan, 1983; Grubb, 1991; Dougherty, 1992; Rouse, 1994) indicates that those who now attend 2-year schools are more often female, come from families with lower family income, and have lower levels of academic achievement than their 4-year counterparts. In addition, President Clinton indicated that he expected a considerable number of welfare recipients to receive training from community colleges as they begin their transition to the labor market (Burgos-Sasscer, 1998). There is also increasing discussion over the role of the community college in training individuals for a more technologically advanced workforce (Leigh \& Gill, 1997; Bates, 1998; Burgos-Sasscer, 1998; Naughton, 1998).

In the present research, our goal is to examine the returns to 2-year versus 4-year degrees with a focus on racial and gender differences in the returns to education. The paper is organized as follows. In the next section, we review the relevant literature to place our work in context. We then discuss our data in the third section. The fourth section details our results and we end with some concluding remarks. 


\section{Literature Review}

Numerous econometric studies of the returns to higher education have been published; many of these have focused on racial differences in these returns (Welch, 1973; Hoffman, 1984; Ashraf, 1994). A growing literature focuses specifically on the sub-baccalaureate market, which includes those in community colleges and junior colleges, whether they are pursuing an associate degree, certificate, or simply additional vocational training. It is the market for those with at least a high school diploma but less than a baccalaureate degree, and is estimated to account for nearly three-fifths of all workers (Grubb, 1997).

Early literature that examined sub-baccalaureate market returns had a very specific focus. Carroll and Ihnen (1967) examined the returns for an investment of 2 years in a technical school. Heinemann and Sussna (1977) examined returns to education at a large, Midwestern urban community college. It was not until the past 10 years that the literature addressing the rate of return to a community college education began growing.

Monk-Turner (1994) examines how the first type of college entered affects future earnings. She uses data from the Parnes National Longitudinal Survey on Labor Market Experiences. In her models, which are not run separately by race and gender, she includes a control for academic ability to overcome potential bias in the returns across type of institution. She finds that those entering a 4-year college when first starting college enjoy a $6.4 \%$ return over those first entering a community college. She concludes that those entering a community college as their first higher education institution are penalized in the long run; their future returns are actually lower in comparison with 4-year college attendees. She notes that community college attendees should not expect to earn as high a rate of return since they invest less in their education as compared with those who attend a 4-year school.

In a comprehensive study, Kane and Rouse (1995) compare the economic returns to 2-year and 4-year colleges using two data sources, the 1990 wave of the National Longitudinal Survey of Youth (NLSY) and the Class of 1972 National Longitudinal Study (NLS-72) across men and women, although not across race. They note that there are differences in the average family backgrounds between students in 2-year and 4-year colleges. Their regressions based on the NLSY data reveal similar returns for men and women to completing an associate degree $(20 \%)$ and completing a baccalaureate degree (33\%). They do find that the returns to some college (attending with no degree receipt) vary between men and women, with the returns typically lower for women. From the NLS-72 data, which has detailed information on credits, they find that completing the baccalaureate degree is important for men while the same is true of the associate degree for women.

Belman and Heywood (1991) were some of the first researchers to examine whether sheepskin effects (effects of completing the degree) vary by race and gender. They use data from the 1978 Current Population Survey to confirm that there is evidence of larger sheepskin effects for women and minorities, although they do not test to see if the differences are statistically significant. They also note that, theoretically, sheepskin effects may vary across demographic groups if degrees provide a stronger productivity signal for some groups than for others. Jaeger and Page (1996) continue Belman and Heywood's work by estimating sheepskin effects for all levels of education for blacks and whites by gender. They use the 1991 and 1992 Current Population Survey to obtain a matched sample of blacks and whites, aged 25-64 years, who were not enrolled in school. One drawback of these data is 


\section{Susan Averett E Sharon Dalessandro}

that they do not include information on ability, family background, or previous work experience. Corresponding to the findings reported by Kane and Rouse (1995), Jaeger and Page (1996) find that for white women associate degrees have statistically significant positive returns, for both vocational and academic degrees. The effect for vocational degrees is substantial when compared with the other groups and is attributed to the nursing programs that women often enroll in, which typically lead to relatively high paying jobs. They also find that white men benefit from academic associate degrees; however, the same finding does not hold for black men. They find little evidence to suggest the existence of different sheepskin effects across gender and race. However, they do find different sheepskin effects by type of degree (e.g., between occupational associate degree and a bachelor's degree) and conclude that sheepskin effects appear to be important.

Building from the empirical findings of Kane and Rouse (1995), Leigh and Gill (1997) examine whether the returns estimated by Kane and Rouse hold for adults who return to attend a community college after several years in the workforce. Leigh and Gill use data from the 1993 wave of the NLSY, when respondents are between the ages of 28 and 35 years, and find that for associate degree recipients the returns are positive and significant. They find no difference in the return to a degree for those students who continue straight from high school and those who return after several years of work experience, despite the fact that the latter are more likely to have families and other responsibilities that might make studying difficult. Finally, they also note that community colleges are increasingly offering non-degree programs to help workers increase their skills. For men, there exists a positive and relatively large $(8-10 \%)$ return to attendance in these non-degree programs.

Grubb has also carried out extensive work in the area of educational returns in the sub-baccalaureate market over the past decade. Grubb (1997) uses the Survey of Income and Program Participation for 1984, 1987, and 1990 to examine several issues. These include questions regarding the existence of economic returns to community college, how those benefits are determined by the credential earned, and whether there are returns above and beyond that due to sheepskin effects or, as Grubb refers to them, program effects. He finds that returns to associate degrees are significant for both men and women, although the rates are lower than a baccalaureate degree. He also finds that the difference in returns between the two degrees is smaller for women than men and that there do appear to be program effects for having degrees or credentials. However, his work suggests that there are substantial variations in the returns to different programs or courses of study for both 2-year and 4-year degrees, and that one must use caution when generalizing returns to a 2-year education since the programs offered are so varied.

\section{Data}

For our analysis, we use data from the NLSY, a large survey of 12686 individuals who have been interviewed since 1979, at which time they were 14-21 years old. Data was available for as recently as 1994 at the time this research was completed. This data set was chosen because it contains extensive labor force, demographic, and schooling information. In addition, minorities and disadvantaged whites are over-sampled, making it possible to estimate the models separately by race.

These data also contain excellent work history information, in particular an accurate measure of previous work experience. Researchers have documented how important a precise measure of previous work experience is in studies of women's 
earnings (Filer, 1993). In addition, we have information on family background (measured by parental education) and ability (measured by the respondent's score on the Armed Forces Qualifications Test (AFQT), a test of academic ability and achievement administered in 1980). Family background and ability are particularly important when considering race and gender differentials in earnings.

We use data from the 1993 survey when the individuals are aged 28-35 years; sample members would have graduated from high school between 1976 and 1983. Thus, they have had ample time to complete an education and to develop an attachment to the labor force, although they are in the early years of their careers. Although data from 1994 are available, previous work experience and earnings are measured for the previous calendar year, necessitating the use of the 1993 survey year. We thus limit our sample to those who were interviewed in 1993, are working, report earnings, and completed high school. Rather than using years of education completed and lacking actual transcript information, we use self-reported information on degree receipt to test for program (sheepskin) effects. We do so recognizing that self-reported degree receipt may bias our estimates of the return to schooling upward (Grubb, 1997).

Following a similar procedure to that outlined by Leigh and Gill (1997), we work backward from 1993 to record the highest degree obtained. For those who did not obtain a degree, we determine whether they attended any college and classify them by the type of college attended. We use six mutually exclusive categories of educational attainment: (1) receipt of an associate degree as the highest degree earned, (2) receipt of a bachelor degree as the highest degree earned without ever having attended a 2-year school, (3) receipt of a bachelor degree as the highest degree earned and also attended a 2-year school, (4) attended only a 2-year school but never completed a 2-year degree, (5) attended only a 4-year school but never completed a 4-year degree, and (6) attended both a 2-year and a 4-year institution without ever completing either degree. The reference category is high school graduates who have never obtained any additional education. Our reason for separating the baccalaureate degree holders into two groups is to see if there is any penalty in the wage return for those who start at a community college and then transfer to finish at a 4-year school. It is possible that some of those earning a baccalaureate degree returned to a 2-year college after earning their 4-year degree to obtain specific skills, such as computer skills. However, our sample sizes do not permit us to separate out those who had their 2-year schooling before their 4-year schooling and those who had it after. We also cannot separate out the baccalaureate degree holders who went on to earn graduate or professional degrees for the same reason.

Our final sample consists of 6413 individuals. Table 1 presents sample means by race and gender. Blacks and whites in the sample attended 2-year schools (and did not earn an associate degree) at fairly similar rates, ranging from 12 to $18 \%$, while blacks were more likely to attend a 4-year school and not earn the baccalaureate degree when compared with whites. Black women were the most likely to attend both a 2-year and a 4-year institution without finishing either degree (about 10\%), while about $6.3 \%$ of the other groups attended but did not finish at both types of schools. About $22 \%$ of the white men and white women earned their baccalaureate degree compared with $16 \%$ of black women and $12.5 \%$ of black men. Of those obtaining a baccalaureate degree, $4.3 \%$ of black men, $4.1 \%$ of black women, $7.6 \%$ of white women, and $6.5 \%$ of black men had also attended a 2 -year institution at some time. Very few $(<2 \%)$ of baccalaureate degree holders had also earned an 
Table 1. Sample means (standard deviations)

\begin{tabular}{|c|c|c|c|c|}
\hline Variable & $\begin{array}{c}\text { Black } \\
\text { Women }\end{array}$ & $\begin{array}{l}\text { Black } \\
\text { Men }\end{array}$ & Women & Men \\
\hline Sample size & 830 & 907 & 2167 & 2509 \\
\hline \multicolumn{5}{|l|}{ Education } \\
\hline Earned an associate degree & 0.098 & 0.051 & 0.095 & 0.069 \\
\hline Earned baccalaureate degree, no 2-year school & 0.123 & 0.084 & 0.158 & 0.157 \\
\hline Earned baccalaureate degree, also 2 -year school & 0.041 & 0.043 & 0.076 & 0.065 \\
\hline Attended a 2-year school & 0.180 & 0.116 & 0.159 & 0.124 \\
\hline Attended a 4-year school & 0.130 & 0.115 & 0.084 & 0.078 \\
\hline Attended both types of schools & 0.099 & 0.063 & 0.062 & 0.063 \\
\hline \multicolumn{5}{|l|}{ Demographic (all pertain to 1993) } \\
\hline Live in North Central region & 0.170 & 0.168 & 0.252 & 0.270 \\
\hline Live in the Southern region & 0.625 & 0.592 & 0.325 & 0.303 \\
\hline Live in the Western region & 0.066 & 0.079 & 0.246 & 0.242 \\
\hline Unsure of region where living & 0.004 & 0.003 & 0.005 & 0.009 \\
\hline Live in an Urban Area & 0.860 & 0.830 & 0.763 & 0.767 \\
\hline Do not know if live in an Urban Area & 0.013 & 0.021 & 0.049 & 0.044 \\
\hline Live in area with $>9 \%$ unemployment & 0.024 & 0.024 & 0.095 & 0.090 \\
\hline Live in area with $<9 \%$ unemployment & 0.345 & 0.353 & 0.266 & 0.265 \\
\hline Live in area where unemployment unknown & 0.004 & 0.003 & 0.005 & 0.009 \\
\hline Age in 1993 (years) & $\begin{array}{l}31.929 \\
(2.225)\end{array}$ & $\begin{array}{l}31.822 \\
(2.217)\end{array}$ & $\begin{array}{l}31.908 \\
(2.257)\end{array}$ & $\begin{array}{l}31.799 \\
(2.238)\end{array}$ \\
\hline Have a child & 0.687 & 0.398 & 0.631 & 0.485 \\
\hline Married & 0.370 & 0.387 & 0.643 & 0.632 \\
\hline Separated, divorced or widowed & 0.243 & 0.169 & 0.187 & 0.135 \\
\hline \multicolumn{5}{|l|}{ Family background } \\
\hline \multirow[t]{2}{*}{ AFQT score } & 25.954 & 23.645 & 48.995 & 48.822 \\
\hline & $(19.527)$ & $(21.704)$ & $(26.109)$ & $(28.319)$ \\
\hline Missing AFQT score & 0.020 & 0.036 & 0.036 & 0.052 \\
\hline Mother is a high school graduate & 0.435 & 0.447 & 0.595 & 0.615 \\
\hline Do not know mother's education & 0.067 & 0.093 & 0.039 & 0.056 \\
\hline Father is a high school graduate & 0.383 & 0.366 & 0.566 & 0.585 \\
\hline Do not know father's education & 0.201 & 0.223 & 0.084 & 0.081 \\
\hline \multicolumn{5}{|l|}{ Employment (all pertain to 1993) } \\
\hline \multirow[t]{2}{*}{ Hourly pay } & 9.940 & 11.030 & 11.800 & 15.150 \\
\hline & $(20.050)$ & $(14.120)$ & $(34.380)$ & $(37.100)$ \\
\hline Employed by government & 0.263 & 0.172 & 0.162 & 0.112 \\
\hline Do not know if employed by government & 0.000 & 0.001 & 0.000 & 0.000 \\
\hline Member of a labor union & 0.166 & 0.186 & 0.104 & 0.141 \\
\hline \multirow[t]{2}{*}{ Experience in 1993 (years) } & 10.022 & 10.717 & 11.236 & 12.145 \\
\hline & $(3.665)$ & $(3.288)$ & $(3.395)$ & $(3.003)$ \\
\hline \multicolumn{5}{|l|}{ Industry } \\
\hline Agriculture, forestry and fisheries & 0.002 & 0.026 & 0.013 & 0.037 \\
\hline Finance, insurance and real estate & 0.073 & 0.037 & 0.089 & 0.048 \\
\hline Manufacturing & 0.133 & 0.232 & 0.138 & 0.23 \\
\hline Mining and construction & 0.007 & 0.096 & 0.015 & 0.145 \\
\hline Public administration & 0.082 & 0.067 & 0.053 & 0.056 \\
\hline Trade & 0.133 & 0.161 & 0.179 & 0.172 \\
\hline Transportation, communications and utilities & 0.080 & 0.118 & 0.051 & 0.088 \\
\hline \multicolumn{5}{|l|}{ Occupation } \\
\hline Precision production, craft and repair & 0.019 & 0.122 & 0.024 & 0.205 \\
\hline Farming, forestry and fishing & 0.004 & 0.035 & 0.008 & 0.034 \\
\hline Operators, fabricator and laborers & 0.137 & 0.341 & 0.08 & 0.227 \\
\hline Service & 0.229 & 0.198 & 0.183 & 0.096 \\
\hline Technical, sales and administrative support & 0.418 & 0.168 & 0.417 & 0.2 \\
\hline
\end{tabular}

associate degree; therefore, we cannot control for having received both degrees in our models. Individuals who received both degrees are classified as having the baccalaureate degree while also having attended a 2-year institution.

We specify and estimate a human capital model where the dependent variable is the natural log of the hourly wage. ${ }^{1}$ We estimate two models for each race/gender 
group. In model 1 , the control variables are a set of basic human capital variables including the dummy variables for various levels of educational attainment, years of previous work experience, age, AFQT score, region of residence, and residence in an urban area. Model 2 adds a richer set of controls, including local unemployment rates, child and marital status, union membership, government employment, parental education, industry, and occupation. ${ }^{2}$ We recognize that selection effects are potentially quite important. In particular, it is possible that those who graduate from a 4-year college would have had higher earnings even without going to college. Thus, following Kane and Rouse (1995) and Leigh and Gill (1997), we control for family background and ability in our models in an attempt to control for possible selection bias. ${ }^{3}$

\section{Estimation Results and Discussion}

Table 2 reports the estimation results by race and gender. Chow tests (see Greene, 1990 , p. 218) confirm that the wage equations should be estimated separately for men and women. Within gender, Chow tests also verify that both models 1 and 2 should be estimated separately for black and white men, but only model 2 is statistically different for black and white women. Because we are presenting all the other models separately by race and gender, we also present model 1 estimated separately for white and black women; the coefficient estimates are similar when we pool and are available from the authors on request.

Beginning with model 1 , there is clearly a value to continuing beyond high school, even if a degree is not earned. For women (black and white) and white men, earning a degree (either associate or bachelor) is always preferable to attending some college but not earning a degree. For black men, the results are less clear; attending both a 2-year and a 4-year institution yields a slightly higher return than an associate degree. Black women tend to get higher returns to all educational categories when compared with white men and white women, while the comparison between black women and black men does not yield any clear pattern. A 4-year degree yields a higher return than a 2 -year degree for all groups. $F$ tests confirm that 4-year degree recipients experience a higher return than those with a 2-year degree. Black women appear to benefit the most from the associate degree, followed by white women. For black men, attending a 2-year school is more valuable than obtaining the 2-year degree. This may be due to the type of programs they are enrolled in or to occupational choice. The returns to a 4-year degree are lowest for white men.

White and black women get essentially the same return to the baccalaureate degree whether or not they started at a 2-year school. However, this is not the case with the men. Interestingly, black men get a return nearly 10 percentage points higher if they get a baccalaureate degree and also attended a 2-year school, although this is not quite statistically significant $(P=0.22)$. However, the reverse is true for white men, who suffer a 5.4 percentage point reduction in the return to the 4-year degree if they also attended a 2-year school. These results are somewhat in contrast to Monk-Turner (1994) who found that those who started in a 2-year program and then transferred earned lower returns to the 4-year degree as compared with those individuals who obtain baccalaureate degrees without ever attending a 2-year institution. This may be related to occupational choice; black men may be in bluecollar occupations that are more closely related to their 2-year schooling, thus this higher return may simply reflect a match between occupation and schooling. Grubb 


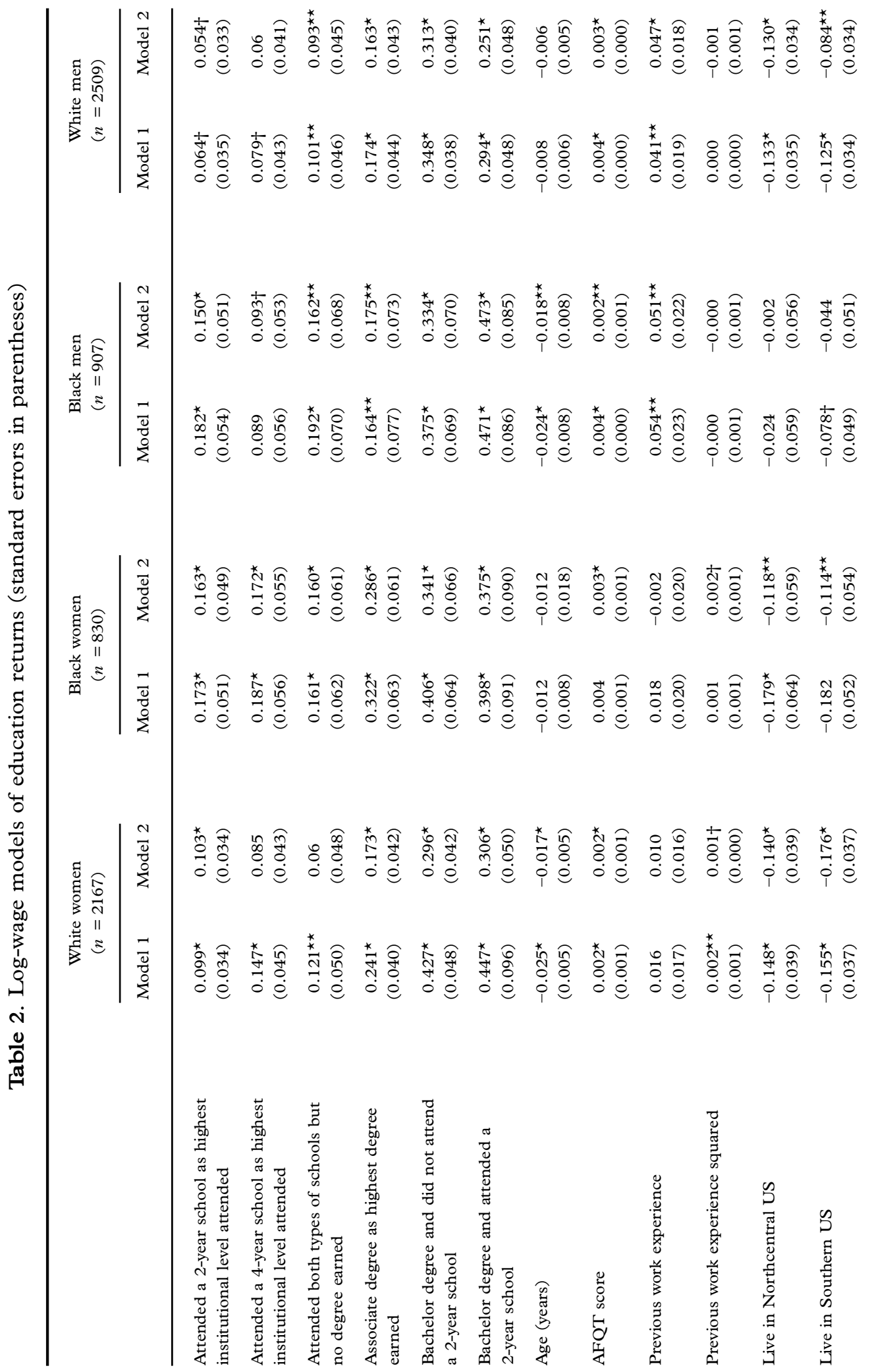






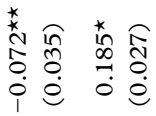

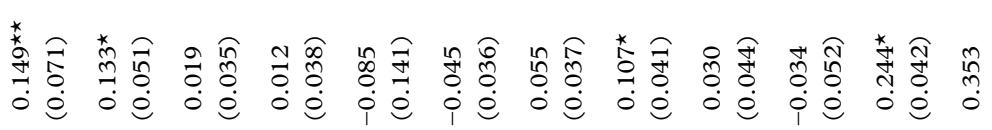

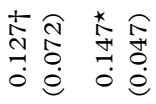

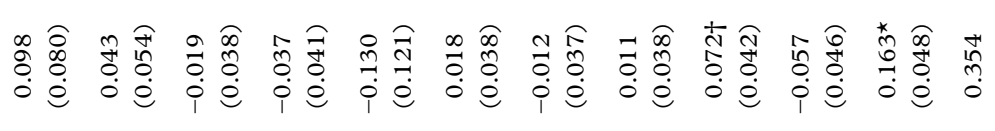

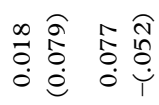

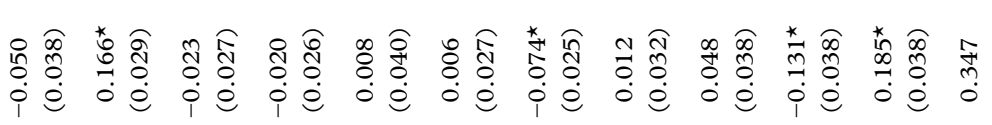

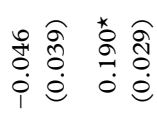

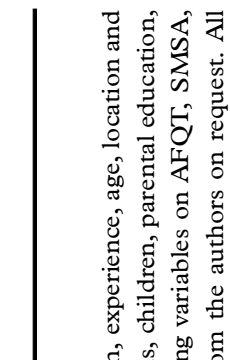

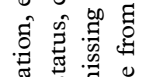

टृ

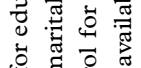

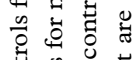

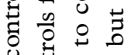

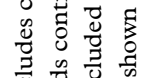

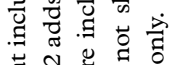

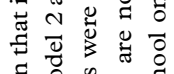

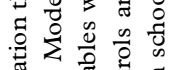

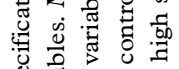

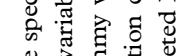

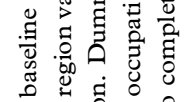

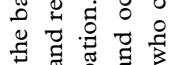

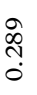

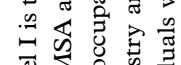

चु

文可

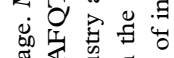

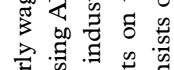

至.

웡

突论

을 专

กิ

vi

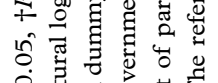

v 沓

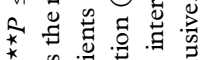

*.

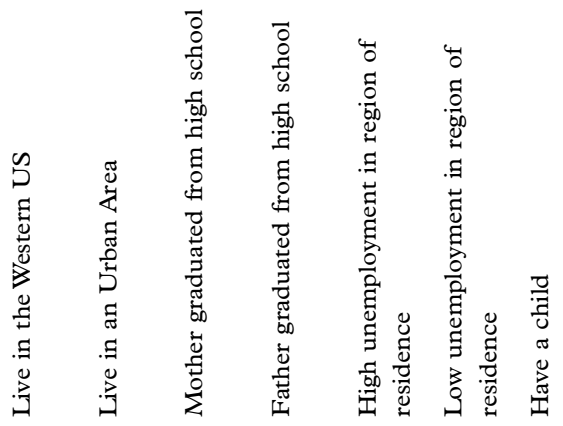

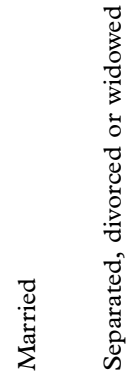

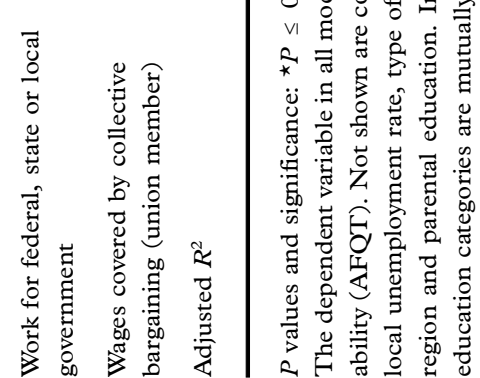


(1997) notes that field of study is an important component to the return to a credential.

In model 2, which has the complete set of controls including occupation and industry, we see that the general pattern of results is the same, although the magnitude of the rates of returns has been dampened somewhat. The coefficients for white women are reduced more than those for the other groups, which may be due to the fact that white women often pursue nursing, a relatively lucrative field (Jaeger \& Page (1996) and Kane \& Rouse (1995) also note a similar finding). One interesting difference is that for white women after controlling for industry and occupation the return to attending both a 2-year and a 4-year school but earning no degree is no longer statistically significant, although it remains significant for the other groups. Another change is that, for black men, controlling for occupation and industry makes the coefficient on obtaining the 2-year degree larger than that of simply attending a 2-year school. The other results are similar to those obtained in model 1. In particular, earning an associate degree is more valuable than attending a 4-year institution without earning a degree, and earning a baccalaureate degree is more beneficial than an associate degree. As before, $F$ tests confirm that the return to a 4-year degree is significantly higher than the return to a 2-year degree for all groups. Finally, controlling for occupation does not change the finding that black men with baccalaureate degrees who attended 2-year schools do better than those who just attended 4-year institutions, whereas the reverse is true for white men.

Although Chow tests confirm that blacks and whites and men and women should be studied separately, to determine whether the returns for blacks and whites are statistically different we pooled the male and female samples by race and interacted race with the education controls. $F$ tests on the race/education interactions reveal that for women the returns are not statistically significantly different by race $(P=0.8141$ for model $1, P=0.7072$ for model 2$)$. For men, the returns are statistically different for model $1(P=0.0842)$ but not for model 2 ( $P$ $=0.4464)$. Thus, there is some evidence that black and white men have statistically different returns to education, although this is sensitive to the inclusion of occupation and industry controls.

\section{Conclusions}

Community colleges have a long history in the United States of providing education for individuals who either lack access to a 4-year college, are looking for a vocational set of skills, or are in need of re-training or additional training after having been in the workforce for some time. The HOPE scholarship provides an economic incentive to earning an associate degree or the first 2 years of a college degree, and it may prove to be an important entry into higher education for segments of the population with fewer financial resources and/or lower academic ability. In this paper, we have documented differences in the returns to education across gender for blacks and whites. We consistently find for each race and gender group that a baccalaureate degree is more valuable than an associate degree, and the return to an associate degree is greater than attending some college. Our results indicate that the returns are statistically different for black and white men, with black men obtaining higher returns to the baccalaureate degree. We also find that for women and white men the return to the 4-year degree is greater when one has not also attended a community college. Interestingly, we find the opposite for black men. Black men who have 4-year degrees but also attended 2-year schools have a higher rate of 
return than if they had not also attended a 2-year school. We also find that controlling for occupation dampens the returns to education, indicating that some of the return to education is really a function of the occupation one selects. However, using occupation and industry as control variables may be problematic if occupational segregation is an issue and blacks and/or women are funneled into lowpaying occupations.

With respect to policy implications, our research indicates that one avenue of low-cost education for women and black men is to attend a 2-year school and then finish the degree at a 4 -year institution. We also find that for white men attending a 2-year school and then obtaining a 4-year degree yields lower returns than simply obtaining a 4-year degree, whereas the reverse is true for black men. This latter finding is not explained by differences in occupation and industry, and therefore deserves further scrutiny.

There are many logical extensions of this research. Perhaps the most important is an investigation into why the returns are different across races. We leave this for future research.

\section{Acknowledgements}

The authors thank Howard Bodenhorn and Michele McLennan for helpful comments. All errors are our own.

\section{Notes}

1. We also ran all of our models with annual earnings as the dependent variable. The pattern of results is similar to those presented here, and these results are available on request from the authors.

2. We started by running four models. The first was the specification labeled model 1 in Table 2 . To this we added controls for children, marital status and parental education. The third model built on the second by adding controls for local unemployment rates, government job, and union membership, and the final model further built on this by adding controls for occupation and industry. We found that the first three models produced virtually identical coefficients for the education variables but when controls for occupation and industry were added the returns to education were smaller. Therefore, in the interest of parsimony, we report only the coefficients from model 1 and the most detailed specification that we label model 2 in Table 2.

3. We do not correct our wage equations for the possible selection bias resulting from selection into employment (and hence observed wages). Other studies (including Leigh \& Gill (1997) and Kane \& Rouse (1995)) do not correct for selection bias from employment either, and we want our results to be comparable with theirs.

\section{References}

Ashraf, J. (1994) Differences in returns to education: an analysis by race, American fournal of Economics and Sociology, 53, pp. 281-290.

Bates, S. (1998) Building better worker's, Nations Business, June, p. 18.

Belman, D. \& Heywood, J. S. (1991) Sheepskin effects in the returns to education: an examination of women and minorities, The Review of Economics and Statistics, 73, pp. 720-724.

Burgos-Sasscer, R. (1998) Path to Houston's job future through HCCS doors, The Houston Chronicle, 4 May, p. A21.

Carroll, A. B. \& Ihnen, L. A. (1967) Costs and returns for two years of postsecondary technical schooling: a pilot study, The fournal of Political Economy, 75, 6, pp. 862-873.

Dougherty, K. J. (1992) Community colleges and baccalaureate attainment, fournal of Higher Education, 63, pp. 188-214. 


\section{Susan Averett E Sharon Dalessandro}

Filer, R. (1993) The usefulness of predicted values for prior work experience in analyzing labor market outcomes for women, fournal of Human Resources, 28, pp. 518-537.

Franey, L. (1998) State and community colleges seek closer ties: University of Missouri hopes to end transfer students' problems, The Kansas City Star, 27 March, p. C4.

Greene, W. H. (1990) Econometric Analysis (New York, Macmillan).

Grubb, W. N. (1991) The decline of community college transfer rates: evidence from national longitudinal surveys, The fournal of Higher Education, 62, pp. 194-222.

Grubb, W. N. (1997) The returns to education in the sub-baccalaureate labor market, Economics of Education, 16, pp. 231-245.

Heinemann, H. N. \& Sussna, E. (1977) The economic benefits of a community college education, Industrial Relations, 16, pp. 345-354.

Hoffman, S. D. (1984) Black-White difference in returns to higher education: evidence from the 1970s, Economics of Education Review, 3, pp. 13-21.

Hoover, R. (1998) Local colleges a bridge to universities: shunned by school of choice? Keep trying, pick transfers, The Detroit News, 10 July, p. C1.

Jaeger, D. A. \& Page, M. E. (1996) Degrees matter: new evidence on sheepskin effects in the returns to education, The Review of Economics and Statistics, 78, pp. 733-739.

Kane, T. J. \& Rouse, C. E. (1995) Labor-market returns to two- and four-year college, The American Economic Review, 85, pp. 600-614.

Leigh, D. E. \& Gill, A. M. (1997) Labor market returns to community colleges: evidence for returning adults, The fournal of Human Resources, 32, pp. 334-353.

McCabe, C. (1998) Community colleges earn credit; best students save on tuition and find transfers are easy, The Boston Globe, 8 February, p. 1.

McCartan, A.-M. (1983) The community college mission: present challenges and future visions, The fournal of Higher Education, 54, pp. 676-692.

Monk-Turner, E. (1994) Economic returns to community and four-year college education, The fournal of Socio-Economics, 23, pp. 441-447.

Morrison, D. G. (1961) What is the place of the community college among higher education institutions, The fournal of Higher Education, 32, pp. 462-463.

Naughton, K. (1998) From the frying pan to the factory, Business Week, 1 June, p. 106.

Rouse, C. E. (1994) What to do after high school: the two-year versus four-year college enrollment decision, in: Ehrenberg, R. G. (Ed.) Choices and Consequences: Contemporary Policy Issues in Education (Ithaca, NY, ILR Press), pp. 59-88.

Rouse, C. E. (1995) Democratization or diversion? the effect of community colleges on educational attainment, fournal of Business and Economic Statistics, 13, pp. 217-224.

Snyder, T. D. (1997) Digest of Education Statistics 1996, NCES 98-015 (Production Manager, C. M. Hoffman; Program Analyst, C. M. Geddes) (Washington, DC, US Department of Education, National Center for Education Statistics).

Welch, F. (1973) Black-White difference in returns to schooling, The American Economic Review, 63, pp. 893-907. 